\title{
INTERNATIONAL TRADE AND THE ENVIRONMENT
}

\author{
Patrick Low
}

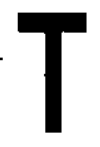

he world's economies are integrated through trade and capital mobility. Should environmental regulations be made more uniform in response to such global integration? Economists say not always, asserting that time and resources may be better spent defining and carrying out sound domestic environmental policy. Environmentalists caution that free trade can be synonymous with sustainable development only if, in the case of natural resources, environmental costs are internalized through such mechanisms as taxes and tradable pollution permits.

The debate covers a wide range of issues-from pollution havens to the political economy of trade in the west to the role of investment and technological change. To shed light on these issues, the World Bank hosted an international conference.

Here are the main points emerging from the proceedings :

1. The effects of growth and trade liberalization on environmental quality are ambiguous. But where appropriate environmental policies are in place, where growth is associated with environmentally friendly technological change, or where trade liberalization reduces environmentally destructive economic distortions or increases productive efficiency, the effects of increased growth on the environment are likely to be positive.

2. Pollution intensity per capita appears to fall as income rises, but evidence of the relationship presented at the conference was based on industrial toxic emissions data, which reflect changes in economic structure (compositional effects) and not the toxic intensity of manufacturing output. Toxic emissions continue to rise worldwide.

3. Fast-growing economies with liberal trade policies (such as Chile) have experienced less pollution-intensive growth than closed economies (such as Bolivia and El Salvador). Again, this is a compositional effect. But the contrast between open and closed economies may be even more pronounced if the relative toxic intensities within industry were taken into account.

4. There is some evidence from the United States that when interest groups link demands for protection from import competition to environmental arguments, they enjoy a higher success rate in securing trade restrictions. The economic consequences of this kind of strategy are generally unfavorable - and the environmental effects at best uncertain. One example is a proposed amendment to the Clean Air Act that would have banned imports of electricity from Canadian power plants that did not meet new U.S. environmental standards (and that would have protected U.S. plants subject to less stringent rules).

5. Pollution abatement and control expenditures by firms do not appear to have had a significant effect on competitiveness in most industries, since these expenditures represent a modest share of total costs. This suggests that national differences in environmental regulations have not been a major explanatory factor in the changing international location pattems of dirty industries. Moreever, rising costs of compliance with environmental standards tend to affect most countries. 
6. Dirty industries have expanded faster in developing countries than the average rate for all industries ober the past two decades - and faster than in industrial countries. It is uncertain, however, whether this international pattern merely reflects growth - or industrial migration as well.

7. It seems that firms have good reason not to transter dirtier technologies to lower-income countries when they invest in these countries. Evidence from the wood pulp industry shows that the rate of clean technology adoption and diffusion is higher in open economies than in closed ones.

\section{Trade Policy and Environmental Objec- tives.}

A key issues in environmental economics is how best to protect the environment. Through command-and-control interventions, such as trade restrictions and the use of pollution abatement funds ? Or through market-based solutions, such as industrial recycling and the diffusion of clean technology? .

The tradition of direct control has dominated environmental policy in industrial countries. Governments prefer direct command-and-control measures for several reasons, according to Patrik Low and Raed Safadi. Regulation generally ensures more predictable outcomes. It assums the public of the government's commitment to environmental quality. And it provides public authorities with discretionary authority over polluters. For these reasons, the shift to more more economically efficient market interventions is likely to be gradual, even in countries with the highest environmental standards. (Such marketbased policy alternatives have been regarded as an option only quite recently.)

In comparing environmental and trade regulations across countries, most economists assume that the capacities to absorb emissions and other concentrations of pollutants vary and that social priorities differ. Differences in absorptive capacities give rise to a different structure of costs and benefits from pollution abatement and control activities and probably influence optimal resource depletion rates. Different social priorities (or discount rates) simply reflect the fact that not all societies embrace identical environmental objectives.

These two propositions may seem obvious and unexceptionable to economists, who think in terms of scarcity, choice, and opportunity cost. But they are not so obvious to those who are tempted to assign an. infinite value to the environment.

Differences in absorptive capacities and social preferences, allow the environment to be treated as an endowment - or as a factor of production that is part of a country's comparative advantage. According to Low and Safadi, it follows that environmental standards and pollution abatement and control activities will differ across countries, and there is no valid. presumption in favor of uniformity or harmonization.

\section{Harmonization ?}

Wide support exists in the environmental community for unified action on the environment by all countries. The harmonization of environmental standards would permit direct control of environmental policy internationally, and as Nemat Shafik puts it, "Harmony in environmental standards allows the imposition of external preferences without the disharmony of gunboat diplomacy." As already noted, differing absorptive capacities and social discount rates argue against uniformity as an international environmental pollicy goal.

In considering such a goal, a distrinction must be made between product standard and process standards. Product standars (relating to externalities in consumption) need to be enforced in the consuming jurisdiction irrespective of the source of the product. This means that harmonization occurs, at least for goods from all sources in a given market, although not necessarily for those goods in all markets. Process standards (externalities in production), however, should gen- 
erally be specific to the location of production.

While calls for the harmonization of process standards are sometimes seen by economists as intrinsically protectionist, environmentalists disagree. Stewart Hudson asserts that such standards are increasingly important, since they account for the life cycle of a product, beginning, with the extraction of natural resources and including the environmental ramifications of transport, marketing, packaging, consumption, and disposal.

In sum, differences in environmental policy whether in standards or in enforcement capacities may not significantly affect a country's advantage over a competing trade partner. However, more research is required. Even if the cost advantages from these national differences are significant, this is no clear case for equalizing costs-or for the harmonization of standards.

\section{Growth, Trade, and Environmental Quality}

An important question, clearly in need of research, relates to the more dynamic aspects of the relationship between growth and trade liberalization on the one hand and environmental quality on the other.

Discussing the links between growth and the environment in general terms, Marian Radetzki argues that increasing levels of economic activity are linked to improved environmental conditions. Explaining this relationship, he identifies as key factors the high income elasticity of demand for environmental quality, compositional shifts toward cleaner environmental activities at higher income levels, and the extension of property rights combined with the development of policies to deal with common global externalities in industrial countries.

From a policy perspective, evidence that the pollution internsity/growth relationship goes the right way argues strongly agains the adoption of antigrowth policies. Policies that factor in environmental externalities may well raise costs and reduce output clearly preferable to an uncritical pursuit of growth at any price. But adopting such an approach should be a matter of adjusting relative prices to reflect social costs and benefits, not of inveighing against increased economic activity because it carries environmental costs and consumes scarce resources. And once environmental policy interventions are contemplated, making the choice between more and less efficient altematives becomes important from a welfare perspective, particularly when absolute pollution continues to rise and environmental crises occur.

Ramon Lopez is less sanguine than many other economists about the extent to which technical progress can mitigate the environmental costs of increasing.economic activity, including that from trade liberalization. He presents a formal model that distingushes between growth with feedback effects (where pollution or resource depletion affects future production) and growth based simply on factor expansion (where today's polluting activities do not affect tomorrow's output). In the first case, there is an incentive to invest in the resource stock to protect its future value and so resource degradation or pollution may decrease with growth, particulariy if appropriate ownership incentives are present. Where growth results simply from factor expansion with no allowance for technological change, the only way pollution can be reduced is through a reduction in output.

\section{Whither dirty industrles ?}

The intensity of pullution is beginning to level off in industrial countries and is increasing in developing countries. Robert Lucas and others relate data on toxic emissions from the United States to cross-country manufacturing output and find that the intensity of emissions grew rapidly in developing countries during the 
1970 s and 1980s. So, dirty industries have certainly moved into developing countries, but have they migrated form industrial countries? Increased toxic intensity in developing countries may merely reflect dispersion, or industrial expansion, rather than migration.

The toxic intensity of output declines as incomes rise only because the share of manufacturing in total output declines beyond a certain level of income. This is a compositional effect. There is no evidence that industry has left industrial countries. Neither is it apparent whether industries have chosen to locate in developing countries, rather than industrial countries, because of more lenient environmental regulation.

Patrick Low and Alexander Yeats use trade flow data as a proxy for shifts in the pattern of international industrial location to examine how much dirty industries have migrated to developing countries over the past two decades. They identify 43 dirty industries based on the assumption that the higher the expenditures on pollution abatement and control, the dirtier an industry. Trade data show that the share of dirty industry trade in total trade declined between 1965 and 1988, largely as a result of trends in industrial countries in the exports of many developing countries increased.

Low and Yeats supplemented that analysis with an examination of the revealed comparative advantage (RCA) of 109 countries in the dirty industries. The RCA index measures whether the share on a product in a country's manufactured exports is proportionately larger than the share of that product in world trade in manufactures. If it is, the country is said to have a revealed comparative advantage in that product. Applying this index to dirty industries showed a disproportionately large increase in the number of developing, countries with RCAs in most of the polluting industries. The rate at which developing countries acquired RCAs in dirty industries in the period under study was four times greater than that of industrial countries and faster than the developing country average for all industries.

The faster, growth of dirty industries in lower-income countries may relate to such considerations as relative labor costs or natural resource endowments. Another possible explanation is that particularkinds of industries, which happen to be relatively dirty, predominate in early stages of industrial development.

An issue in need of further research is whether firms that locate in low-income countries are dirtier than they would be if they located in industrial countries. Firms may wish to eschew this strategy even in it appeared that differences in environmental regulation offered a competitive advantage. Reasons include fear of liability in the event of an environmental accident, the risk to a firm's reputation from an environmental scanda!, the demends of consumers ("green consumerism") in export markets, anticipation of more stringent local environmental standards, and the relatively high costs of retrofitting aging capital equipment rather than starting out with top-of-the-line technology. Another is the cost of unbundling technology, such as the expense of shifting from "cleaner" production processes to older, "dirtier" ones.

Nancy Birdsall and David Wheeler show that dirtier industries tend to be located in less open economies in Latin America. If economies with open trade regimes attract more foreign investment than closed ones, these technological factors are likely to be at work to a greater degree in the open economies. So, there may be an even stronger casse from an environmental perspective for promoting liberal trading arrangements in developing countries than suggested by the industry compositon data alone. Birdsall and Wheeler present some anecdotal evidence from Chile of the positive link between openness and the transfer of environmentally. clean technology. 
International cooperation and the environment.

Looking at various aspects of international cooperation, Low and Safadi argue that trying to coerce countries into adopting particular environmental policies on the basis of unilateral objectives is unlikely to raise environmental quality. Where punitive trade vestriction are involved, the costs of inefficiency associated with inappropriate interventions must also be considered. Environmental targets are more likely to be attained through cooperative arrangements that involve incentives than through those that involve threats.

Analyzing alternative policy approaches to dealing with international environmental externalities, Ishac Diwan and Nemat Shafik demonstrate how, in a situation of less than perfectly functioning markets for capital and emissions, the opening of one market and not the other may lead to a harmful environmental outcome. This is an application of the theory of the second best.

Diwan and Safik also establish the case for compensation, especially where industrial and developing country environmental priorities differ, and where developing countries are expected to respond to industrial country concerns. While industrial countries worry about such issues as climate change and biodiversity, developing countries are much more preoccupied with domestic problems such as health and local pollution.

Making a careful analysis of alternative compensatory mechanisms, Diwan and Shafik look at current cash transfers, debtfornature swaps, technology transfers, and sanctions for nature (this is retaliatory or conditional rather than compensatory). The only one of these mechanisms that is not accompanted by adverse side effects is the transfer of clean or pollution-reducing technology. Under the assumptions of the model developed by Diwan and Shatik, the negative effects of inappropriate compensatory menchanisms can be significant. This analysis stresses the importance of making efficient choice one a policy course has beeen decided on.

Piritta Sorsa examines how the rules of the General Agreement on Tariffs and Trade (GATT) deal with environmental issues. She explores the GATT rules on border adjustments (nondiscrimination and national treatment), public policy exceptions, the standards codes, and rules on dumping, subsidies, and countervailing duties. Sorsa concludes that, since trade itself is rarely the source of an environmental problem, there is little sense in using trade policy to address such problems. It seems that the GATT poses little threat to the pursuit of legitimate environmetnal objectives (in contrast to hidden protection).

At most, the GATT may be in need of a little clarification, as with the rules on border adjustments, where an incentive is provided for the suboptimal use of environmental taxes.

According to Stewart Hudson, one approach would be for the GATT and other international agreements and protocols to make reforms in anticipation of the trrend among nations to adopt process standards and trade measures that affect both natural resources and manufactured goods. Rather than fight the tide, GATT and trade negotiators should work on how to avoid the use of process standards as protectionist devices. 